\title{
Molecular Diagnosis of a Cutaneous Form of Pox in Pigeons at Mhow in Madhya Pradesh, India
}

\author{
S.D. Audarya ${ }^{1 *}$, T. Riyesh $^{2}$, N. Kumar ${ }^{2}$, D. Chhabra ${ }^{1}$, R. Sikrodia ${ }^{1}$, \\ R. Sharda ${ }^{1}$, S. Barua ${ }^{2}$ and U.K. Garg ${ }^{3}$ \\ ${ }^{1}$ Department of Veterinary Microbiology, College of Veterinary Science and Animal \\ Husbandry, Nanaji Deshmukh Veterinary Science University, Mhow-453446, \\ Madhya Pradesh, India \\ ${ }^{2}$ National Center for Veterinary Type Cultures, Indian Council of Agricultural Research- \\ National Research Center on Equines, Sirsa Road, Hisar-125001, Haryana, India \\ ${ }^{3}$ Department of Veterinary Pathology, College of Veterinary Science and Animal Husbandry, \\ Nanaji Deshmukh Veterinary Science University, Mhow-453446, Madhya Pradesh, India \\ *Corresponding author
}

\section{A B S T R A C T}

\begin{tabular}{|l|}
\hline K e y w o r d s \\
Avian pox, P4b \\
gene, PCR, Pigeon
\end{tabular}

\section{Introduction}

Avian poxviruses infect domestic and wild birds (Carulei et al., 2017). As many as 278 species from 70 families in 20 orders of birds including pigeons are affected by poxviruses naturally. Large poxviruses are double stranded enveloped DNA viruses. These poxviruses are categorized into the genus Madhya Pradesh.
Avian poxviruses cause pox in different kind of birds. In the present study, investigations of a cutaneous form of pox in pigeons were reported. In June 2017, a Pigeon showing clinical lesions of yellowish crust/nodules on and around beak and eyes and feet was observed in a scattered group of around 40 pigeons. Lesions were collected aseptically in a container with $50 \%$ glycerol phosphate buffer solution. After processing of clinical specimen the inoculums were inoculated into chicken embryonated eggs by using chorioallantoic membrane route. Viral deoxyribonucleic acid was extracted and used in Avipox virus specific polymerase chain reaction. No specific lesions were observed in inoculated chicken embryonated egg even after third passage. However, in polymerase chain reaction Avipox virus specific P4b gene (578 bp) was successfully amplified and visualized in $1 \%$ agarose gel on electrophoresis. Clinical signs and amplification of Avipox virus specific gene confirmed cutaneous form of Pox in Pigeons at Mhow in

Avipoxvirus of the Chordopoxvirinae subfamily in the Poxviridae family. There are 13 recognised species in the genus Avipoxvirus (WHA, 2012). Avian pox occurs frequently in domestic poultry, pigeons and canaries (Mayahi and Talazade, 2010). Pigeons are members of the order Columbiforme and domestic pigeon is known as Columba livia. Pigeon pox infections 
caused by the pigeon poxvirus in the subgroup Avian poxvirus generally exhibit two forms: cutaneous (dry-discrete scabby lesions on unfeathered parts of the body especially the beak and eyelids) and diphtheritic (wetfibronecrotic diphtheritic lesions in the oropharynx). The incubation period is 7-9 days. Usually lesions heal in 3-4 weeks except diphtheritic lesions may persist for months. Poxviruses are present in the scabs and because they are resistant to drying, remain stable in the environment. Though a selflimiting disease, at times because of lesions which are painful and infections due to secondary bacteria it may interfere with bodily functions. Scabs when removed forcibly may result in bleeding and deformity. The Pigeon poxvirus enters the body through the mucous membranes or wound to the skin.

The Pigeon poxvirus is transmitted primarily by direct contact through fighting, feather picking or indirectly by mosquitoes bites. Due to localization of the virus at point of entry it may cause localised infection. When the virus spread through blood to the liver and bone marrow, there may be a systemic infection (Doneley, 2006). In severe cases affected birds die within 10-20 days on catching the infection. Mild cases are found in small percentage of birds and they usually recover. Recovered birds are immune. Young affected birds surviving the disease remain underdeveloped and never recover to their full strength (Graham and Barger, 1935). In the present study investigations of a cutaneous form of Pox in Pigeons at Mhow in Madhya Pradesh was reported.

\section{Materials and Methods}

\section{Pigeons}

Pigeons are generally spotted roosting in and around the buildings of College of Veterinary Science and Animal Husbandry, Mhow-
453446, Indore, Madhya Pradesh. From a scattered group of 40 pigeons (some are having nests inside the buildings), 2 mortalities were recorded and an affected pigeon was spotted in the lobby of the main buildings on Thursday, $1^{\text {st }}$ June 2017 in the evening hours.

\section{Collection and storage of clinical samples}

Nodules/scabs on and around the beak and feet were collected aseptically and pooled in a sterile container with $5 \mathrm{ml}$ of $50 \%$ glycerol phosphate buffer solution. The collected samples were stored at $+4^{\circ} \mathrm{C}$.

\section{Processing of specimen and storage}

Pooled samples were taken out from the refrigerator and placed in the mortar containing $10 \mathrm{ml}$ of phosphate buffer saline solution and sterile glass beads with antibiotics at room temperature. After grinding it with the pestle, the resultant mixture was centrifuged at $3000 \mathrm{rpm}$ for $5 \mathrm{~min}$ at $+4^{\circ} \mathrm{C}$. The supernatant was placed in the sterile centrifuge tube and kept at $-20^{\circ} \mathrm{C}$ in the deep freezer at the Veterinary Microbiology departments in the College of Veterinary Science and Animal Husbandry, Mhow and College of Veterinary Science, Hisar.

\section{Inoculation of chicken embryonated eggs}

For the study, chicken embryonated eggs of Kadaknath birds were procured from Kadaknath poultry unit of Poultry Science Department of the College and also in Specific Pathogen Free (SPF) chicken embryonated eggs at National Center for Veterinary Type Cultures.

The eggs were observed under egg Candler and viable eggs were incubated. Viable eggs of 10 days old were used in the present investigation. 
Transport of samples to National Center for Veterinary Type Cultures

Supernatants resulting after the processing of specimen were handed over to and scabs were sent by speed post under cold chain conditions.

\section{Recovery of Avipox virus}

Virus (es) were recovered from the clinical specimens in Minimum Essential Medium (MEM, Sigma, Steinheim, Germany) and filtered through $0.45 \mu \mathrm{m}$ filter.

Extraction of viral deoxyribonucleic acid (DNA)

The viral DNA was extracted using Viral RNA/DNA Purification Kit (Thermoscientific, Vilnius, Lithunia).

\section{Primers}

Following primers were used to amplify 578 bp fragment of DNA polymerase gene of Avipox virus; forward primer: 5'CAGCAGGTGCTAAACAACAA-3' and reverse primer: 5'CGGTAGCTTAACGCCGAATA-3' (Huw and Hwa, 1997; Masola et al., 2016).

\section{Avipox-specific polymerase chain reaction}

For amplification of Avipox-specific P4b gene in PCR, each reaction tube of $20 \mu \mathrm{l}$ contained $10 \mu 1$ of $2 X$ PCR master mix (Promega, Madison, USA), 20 pmol of forward and reverse primers and $2 \mu \mathrm{l}$ of DNA (template). The thermocycler conditions were as follows: a denaturation step of $5 \mathrm{~min}$ at $95^{\circ} \mathrm{C}$ followed by 38 cycles of amplification $\left(30 \mathrm{sec}\right.$ at $95^{\circ} \mathrm{C}$, $30 \mathrm{sec}$ at $55^{\circ} \mathrm{C}$, and $30 \mathrm{sec}$ at $72^{\circ} \mathrm{C}$ ), and a final extension step at $72^{\circ} \mathrm{C}$ for $10 \mathrm{~min}$. Positive, negative and no template controls were kept in the experiment.
Agarose gel electrophoresis and documentation of the results

The amplified Avipox gene specific deoxyribonucleic acid products in PCR were run in $1 \%$ agarose gel electrophoresis to find out the positive samples. The results obtained on completion of agar gel electrophoresis were recorded and documented using gel documentation system.

\section{Results and Discussion}

Cutaneous form of avian pox in pigeons was reported from Andhra Pradesh and lesions noticed were round, nodular, greyish white eruptions around the eye, on the beak, skin, legs and around the cloaca of affected birds (Hemanth et al., 2014). Recently concurrent occurrence of cutaneous and diphtheritic forms of pigeon pox disease was reported from Srinagar, Jammu and Kashmir. Scattered multifocal firm grayish white nodules were seen around the eyes, beak and both the legs in a pigeon pox affected Pigeon. And also there were multiple light yellowish nodules observed on the mucosa of mouth, pharynx and larynx (Jan et al., 2017).

Similar lesions are observed in the present investigation but only of cutaneous form of pigeon pox (Fig. 1). In another study cutaneous form of pox in a flock of pigeons at Kadapa district of Andhra Pradesh and its successful therapeutic management with azithromycin was reported (Sudhakara and Sivajothi, 2017). Similarly oral administration of Acyclovir @ $80 \mathrm{mg} / \mathrm{kg}$ every $6 \mathrm{hr}$ for 10 days in canaries was used to treat Canary pox. Therapeutic management of the affected bird in the present investigation was not possible since it died very soon.

Beaudette and Hudson in 1938 discovered that pigeon-pox virus can be grown readily in eggs by serial passage. 
Fig.1 Pigeon showing clinical signs of Avipox (Pigeon pox) A) Yellowish crust/nodules on and around the beak, over and under the left eye B) Lesions on right side of the pigeon on the beak and around the eye $\mathrm{C}$ ) Lesions on feet

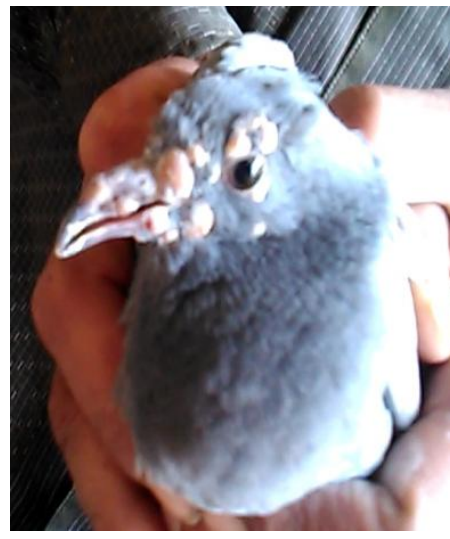

(A)

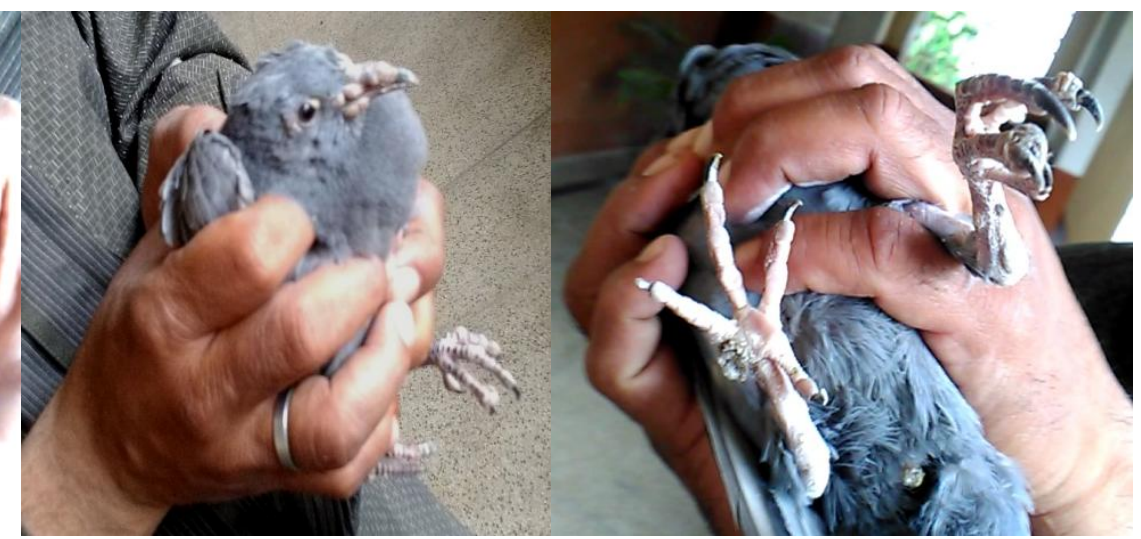

(B)

(C)

Fig.2 Amplification of Avipox virus specific gene (Wells: 1-100 bp marker, 2-Positive control, 3-No template control, 4-Negative control, 5, 6, 7-Samples, 578 bp)

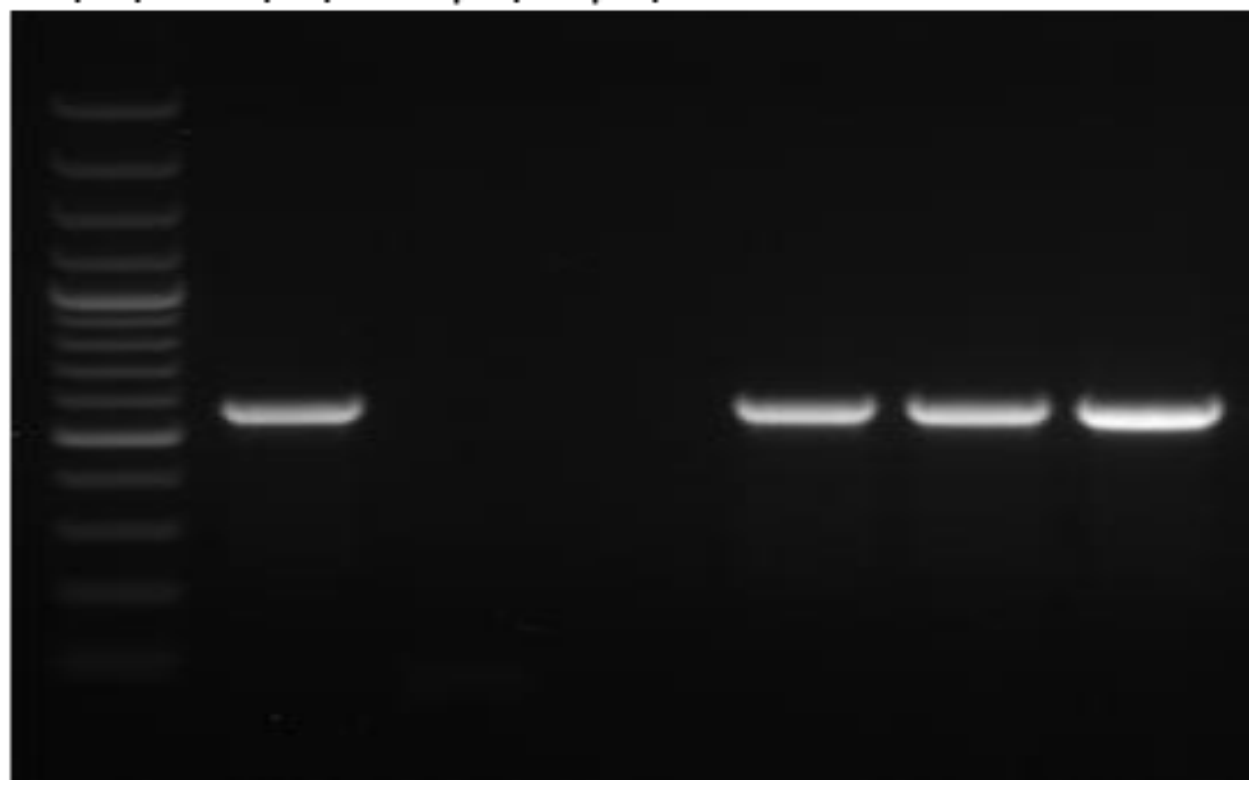

In one of the other studies, generalized white foci and oedematous thickening were recorded after first passage and subsequent passages led to pock size of about $2-5 \mathrm{~mm}$ in diameter along with haemorrhage congestion and necrosis (Khan, 2014) in embryonated chicken eggs. However in our study even after three blind passages in SPF eggs and one in desi Kadaknath bird's embryonated eggs no specific lesions were observed in inoculated embryonated chicken eggs. Similarly, Tanzanian strain of pigeon pox virus isolated from domestic pigeon is not pathogenic in chickens (Masola et al., 2016). So further studies are planned to know whether the Pigeon pox virus in the study adapt to the embryonated chicken eggs with or without any lesions (Bayati, 2017). 
Pigeon pox vaccines in healthy fowls produce modified form of immunity against fowl pox which may be demonstrated as soon as two weeks following vaccination. Pigeon pox vaccine is used with less risk than fowlpox vaccines as fowlpox vaccines are associated with systemic reaction and temporary loss of egg production in chickens (Graham and Barger, 1935). But the immunity produced by Pigeon pox vaccines is limited and after 3 months it decreases (Haig et al., 1951). Isolation of the Pigeon pox virus from the specimen collected in the present investigation is planned to study host specificity of the virus to the Pigeons and Chickens. As in one of the study field isolates of Pigeon pox virus and fowl pox virus from Bangladesh exhibited considerable host specificity (Siddique et al., 2011).

In the present study successful amplification of Avipox-specific P4b gene from scabs taken from the affected pigeon in polymerase chain reaction further confirmed the avian pox viral infection (Fig. 2). All avian poxvirus genomes differ from other poxvirus genomes (Carulei et al., 2017). So in future after isolation of Pigeon pox virus whole genome sequencing of the Pigeon pox can be attempted to understand genetic features of the isolate.

Vaccines against Pigeon pox are administered by follicle method and subcutaneous injection. Presently Chevipok® vaccine by chevita $\mathrm{GmbH}$ is administered in young pigeons $\left(9^{\text {th }}\right.$ week of age) by any of the above methods and in adult pigeons (5 weeks before mating, follicle method and 3 weeks before mating (subcutaneous injection). In case of follicle method annual booster vaccination is desirable. The immunity develops 21 days post subcutaneous injection of the vaccine and minimum duration of appreciable immunity is for up to 9 months duration. Another Pigeon pox vaccine (chicken embryo propagated, freeze dried, live virus vaccine) from Hygieia biological laboratories, California is available for immunization in chickens but not for Pigeons. Colombovac $\AA$ $\mathrm{PMV} /$ pox from zoetis and Medipox vaccine from Medpet is available. In India though fowl pox vaccines are produced, no such vaccines against Pigeon pox are produced or available commercially. Hence in future, if Pigeon pox virus is successfully isolated then it can be used in preparation of vaccine. More than 40 types of parasites live either on the birds or in the places they roost and are responsible for transmission of infectious agent including pox (Bahrami et al., 2013). Besides vaccination, isolation of diseased pigeons, preventing mosquito biting are effective measures for prevention and control of Pigeon pox. The present investigation reports cutaneous form of pox in Pigeons and further it is confirmed by successful amplification of Avipox-specific $\mathrm{P} 4 \mathrm{~b}$ gene in polymerase chain reaction test.

\section{Acknowledgements}

The author expresses deepest gratitude and reverence to Late Dr. U.K. Garg, Dean for spotting the affected bird and informing. Thanks are due to Dr. L. Chauhan (for providing chicken eggs), Mr. R. Chauhan (for catching and holding the bird safely for photography) and to Dr. N.K. Kakker, Dr. R. Chhabra and Dr. D. Sharma (for their help in storage and transportation of the samples at Hisar).

\section{References}

Bahrami, A.M., Hosseini, E. and Razmo, M. 2013. Important parasite in pigeon, its hematological parameter and pathology of intestine. W. Appl. Sci. J., 21(9): 1361-1365.

Bayati, H.A.M.A. 2017. Virological study about Avipox virus in local birds of Iraq. Int. J. Sci. Res., 6(6): 766-769. 
Beaudette, F.R. and Hudson, C.B. 1938. Cultivation of pigeon pox virus on the chorioallantoic membrane. J. Am. Vet. Med. Assoc., 93(3):146-150.

Carulei, O., Douglass, N. and Williamson, A.N. 2017. Comparative analysis of avian poxvirus genomes, including a novel poxvirus from lesser flamingos (Phoenicopterus minor), highlights the lack of conservation of the central region. BMC Genomics, 18: 1-13

Doneley, B. 2006. Pigeon medicine and surgery. The North American veterinary conference. Exotics-Avian, pp. 15251530 .

Graham, R. and Barger, E. 1935. Fowl pox. Circular 430, University of Illinois, College of Agriculture: Agricultural experiment station and extension services. Pp14.

Haig, D.A. 1951. Fowl-pox vaccination in South Africa with egg propagated fowl and pigeon pox viruses. Onderstepoort J. Vet. Res., 25(1): 17-29.

Hemanth, I., Amravathi, P., Sasidhar, B.N., Anand, K.A. and Sailaja, N. 2014. An outbreak of cutaneous form of avian pox in pigeons (Columbia livia). Int. J. Sci. Environ., 3(4): 1484-1488.

Huw, L.L. and Hwa, L.K. 1997. Application of the polymerase chain reaction for the diagnosis of fowl poxvirus infection. $J$. Virol. Methods, 63: 113-119.

Jan, A., Shah, O.S., Moona, S.M., Ali, R., Rasool, S. and Asfar, A. 2017. Concurrent occurrence of cutaneous and diphtheritic form of pigeon pox in pigeon (Columbia spp.) and its successful amelioration by garlic and honey. The Pharma Innov. J., 6(12): 494-495.

Khan, F.F. 2014. Studies on field strain of pigeon pox virus and its comparison with field and vaccine strains of fowl pox virus. MVSc. Thesis submitted to Department of Veterinary Microbiology, College of Veterinary and Animal Husbandry, Chattisgarh Kamdhenu Vishwavidyalaya, Anjora, Durg.

Masola, S.N., Mzula, A., Kasanga, C.J. and Wambura, P.N. 2016. Evaluation of virulence of Tanzanian strains of fowlpox and pigeonpox viruses in chickens. Br. Biotechnol. J., 10(1): 110.

Mayahi, M. and Talazade, F. 2010. Case report: treatment of canary pox with orally administration of Acyclovir. $J$. U.S.-Chin. Med. Sci., 7(4).

Siddique, A.B., Hossain, M.A. and Zinnah, M.A. 2011. Determination of host specificity of pigeon pox and fowl pox viruses isolated from a field outbreak. Bulgarian J. Vet. Med., 14(4): 2019214.

Sudhakara, R.B. and Sivajothi, S. 2018. Therapeutic management of cutaneous form of pox in pigeons with azithromycin. Int. J. Avian Wildl. Biol., 3(3): 143-144.

Wildlife health Australia. 2012. Poxviruses and Australian Wild birds, Fact sheet, 16.

\section{How to cite this article:}

Audarya, S.D., T. Riyesh, N. Kumar, D. Chhabra, R. Sikrodia, R. Sharda, S. Barua and Garg, U.K. 2018. Molecular Diagnosis of a Cutaneous Form of Pox in Pigeons at Mhow in Madhya Pradesh, India. Int.J.Curr.Microbiol.App.Sci. 7(09): 1318-1323. doi: https://doi.org/10.20546/ijcmas.2018.709.157 